\title{
Gastrointestinal parasites of bottlenose dolphins Tursiops truncatus from the extreme southwestern Atlantic, with notes on diet composition
}

\author{
María Alejandra Romero ${ }^{1,2,3, *}$, Mercedes Fernández ${ }^{4}$, Silvana L. Dans ${ }^{5}$, \\ Néstor A. García ${ }^{5}$, Raúl González ${ }^{1,2,3}$, Enrique A. Crespo ${ }^{5}$ \\ ${ }^{1}$ Instituto de Biología Marina y Pesquera Almirante Storni (IBMPAS), Güemes 1030, 8520 San Antonio Oeste, Río Negro, \\ Argentina \\ ${ }^{2}$ CONICET, Rivadavia 1917, 1033 Ciudad Autónoma de Buenos Aires, Argentina \\ ${ }^{3}$ Escuela Superior de Ciencias Marinas, Universidad Nacional del Comahue, San Martín 247, 8520 San Antonio Oeste, \\ Río Negro, Argentina \\ ${ }^{4}$ Marine Zoology Unit, Cavanilles Institute of Biodiversity and Evolutionary Biology, University of Valencia, PO Box 22085, \\ 46071 Valencia, Spain \\ ${ }^{5}$ Centro Nacional Patagónico (CENPAT/CONICET), Bvd. Brown 2915, 9120 Puerto Madryn, Argentina
}

\begin{abstract}
We surveyed the gastrointestinal tracts of 6 bottlenose dolphins Tursiops truncatus from Patagonia to check for helminth parasites and characterize dolphin diet. All dolphins harbored parasites (6477 helminths). We recorded 7 species, including nematodes Anisakis simplex s.l., Pseudoterranova decipiens, acanthocephalans Corynosoma cetaceum, C. australe, and digeneans Braunina cordiformis, Pholeter gastrophilus and Synthesium tursionis. Among the gastric helminths, the most prevalent species were C. cetaceum and A. simplex while C. australe and $S$. tursionis inhabited the intestine at low prevalence. This is the first report of $C$. australe and $P$. decipiens in bottlenose dolphins. Regarding diet, 5 stomachs contained food remains (consisting of 103 prey items). The most important prey species were Geotria australis and Stromateus brasiliensis, but their role in parasite transmission is unclear. At the community level, the gastrointestinal parasite community of $T$. truncatus was depauperate and strongly overlapped the community described for pelagic dolphins inhabiting Patagonia, suggesting a strong local influence in shaping helminth communities. Nevertheless, these observations are at odds with the notion that oceanic cetaceans have comparatively poorer helminth fauna than neritic species such as bottlenose dolphins, due to the lower likelihood of parasite exchange.
\end{abstract}

KEY WORDS: Tursiops truncatus - Corynosoma - Anisakis - Pseudoterranova - Braunina · Pholeter · Synthesium · Patagonia · Argentina · Southwestern Atlantic

-Resale or republication not permitted without written consent of the publisher

\section{INTRODUCTION}

Studies of parasite assemblages produce valuable information about various aspects of marine mammals. Parasites have proved especially useful markers of contemporary and historical ecological and evolutionary relationships, providing information on host ecology, biogeography and phylogeny (Hoberg \& Klassen 2002, Byers 2009). Furthermore, parasites are important biological tags for characterizing useful information about host social structure, stock identity, movements and other ecological aspects which are relevant for population conservation and management (Aznar et al. 1995, MacKenzie 2002). 
Parasitism can also cause disease, which may have a considerable impact on marine mammal populations, and can even have an impact on human public health and economics (Harwood \& Hall 1990, Dubey et al. 2003).

Research into the parasite fauna of marine mammals is on the rise, particularly in odontocetes inhabiting the southwestern Atlantic. Aznar et al. (1994) conducted one of the first studies in this area, reporting on helminth communities of franciscana Pontoporia blainvillei in Argentine waters. Dans et al. (1999) reported the gastrointestinal helminths of the dusky dolphin Lagenorhynchus obscurus off the Patagonian coast. More recently, novel information has been published on Commerson's dolphin Cephalorhynchus commersonii (Berón-Vera et al. 2001), the hourglass dolphin L. cruciger (Fernández et al. 2003) and on the common dolphin Delphinus delphis (BerónVera et al. 2007). Other studies have described occasional strandings of poorly known cetaceans, such as spectacled porpoises Phocoena dioptrica, Burmeister's porpoise Phocoena spinipinnis, Gray's beaked whale Mesoplodon grayi, Cuvier's beaked whale Ziphius cavirostris, sperm whale Physeter macrocephalus and Hector's beaked whale Mesoplodon hectori (Aznar et al. 2003, Berón-Vera et al. 2008, Nikolov et al. 2010). These studies explored parasite transmission within a trophic web, as well as host habitat distribution, reporting new helminth taxa or describing helminth communities of by-caught or stranded dolphins.

Bottlenose dolphins Tursiops truncatus inhabit a wide range of coastal and pelagic habitats throughout tropical and temperate waters worldwide (Leatherwood \& Reeves 1990, Wells \& Scott 1999). In the Southern Hemisphere, bottlenose dolphins live as far south as Tierra del Fuego, South Africa, Australia, and New Zealand. Limits to this species' range appear to be temperature-related, either directly or indirectly through prey distribution (Coscarella et al. 2012). This species is one of the most intensively studied odontocete species worldwide (Wells \& Scott 1999). However, data are scarce for the southwestern Atlantic Tursiops populations, and more information is required on several aspects of their life history and stock identity to better understand regional ecology and population trends. These include natural mortality factors, feeding habits, fishery interactions, and parasites. The lack of such information delays the design and implementation of management and conservation actions.

Most literature concerning the parasite fauna of bottlenose dolphins comes from checklists (e.g. Dai- ley \& Brownell 1972) or studies focusing on a single helminth species (e.g. Raga et al. 1985a,b, Fernández et al. 1994), and most studies have been conducted in the Northern Hemisphere. One of the most recent surveys of bottlenose dolphin parasite fauna was performed by Quiñones et al. (2013) in the Mediterranean. Researchers have found the following taxa among the gastrointestinal community of Tursiops truncatus: the digeneans Braunina cordiformis, Synthesium tursionis, Brachycladium atlanticum, and Pholeter gastrophilus; the acanthocephalans Bolbosoma sp. and Corynosoma cetaceum; the nematode Anisakis simplex; and the cestodes Tetrabothrius forsteri, Diphyllobothrium sp. and Strobilocephalus triangularis (Schryver et al. 1967, Dailey \& Brownell 1972 and references therein, Bowie 1984 and references therein, Quiñones et al. 2013). However, there are no community-based analyses of the parasites of T. truncatus in the Argentine shelf, including Patagonia. Our lack of knowledge about this species in the region is probably due to the low frequency of dolphin strandings or by-catches.

The paucity of published data on parasites inhabiting bottlenose dolphins in Patagonian waters and the need to gather more detailed information regarding their biology and ecology prompted the present study. Our main objective was to describe the gastrointestinal parasite fauna at the infra and component population levels in the southern limit of Tursiops truncatus' distribution in the southwestern Atlantic. We also characterized their diet in order to assess potential helminth transmission routes.

\section{MATERIALS AND METHODS}

\section{Parasitological analysis}

A total of 6 dead, stranded bottlenose dolphins ( 4 females, 1 male, and 1 individual of unknown sex) were recovered from the northern Patagonia coast $\left(40^{\circ} 30^{\prime}\right.$ to $43^{\circ} 30^{\prime} \mathrm{S}, 64^{\circ}$ to $\left.65^{\circ} \mathrm{W}\right)$ between 1997 and 2012. All specimens were in a stage of decomposition of 2 to 3, sensu Geraci \& Lounsbury (2005). Animals were necropsied within $24 \mathrm{~h}$ of stranding using standard techniques (Geraci \& Lounsbury 2005), either in the field or laboratory. Body length ranged from 205 to $324 \mathrm{~cm}($ mean \pm SD: $289.9 \pm 48.6$; Table 1$)$.

Following post-mortem examination, the complete digestive tract was removed from the carcasses and kept frozen at $-20^{\circ} \mathrm{C}$. After thawing, each stomach chamber (i.e. forestomach, main stomach, pyloric stomach and duodenal ampulla) was analyzed sepa- 
Table 1. Tursiops truncatus sampling data. F: female; M: male; ND: not determined. Dates are d/mo/yr

\begin{tabular}{|lccc|}
\hline ID & Sex & Size $(\mathrm{cm})$ & Stranding date \\
\hline Tur tru 001 & F & 319 & $11 / 07 / 1997$ \\
Tur tru 002 & F & 300 & $22 / 12 / 1999$ \\
Tur tru 004 & F & 301.5 & $21 / 07 / 2005$ \\
Tur tru 005 & F & 205 & $21 / 07 / 2008$ \\
Tur tru 006 & ND & ND & $07 / 09 / 2008$ \\
Tur tru 009 & M & 324 & $11 / 04 / 2012$ \\
\hline
\end{tabular}

rately. Intestinal tracts from 5 individuals (specimen Tur tru 002 was in poor condition, and was therefore excluded from the analysis) were divided into 20 sections of equal length. Parasites were isolated from food contents and recovered with a $0.2 \mathrm{~mm}$ mesh sieve. Additionally, the stomach and intestinal walls were examined, and attached worms collected. Parasites were flushed in saline solution, fixed and preserved in $70 \%$ ethanol until examination.

All individual helminths collected from each host were counted under a stereomicroscope. Nematodes were cleared in alcohol-glycerin (1:1), and digeneans were stained with iron acetocarmine for identification (Georgiev et al. 1986). We used ecological terminology following Bush et al. (1997), and estimated infection parameters according to Rózsa et al. (2000). The $95 \%$ confidence intervals (CI) for prevalence and species richness were set with Sterne's exact method (Reiczigel 2003); 95\% CIs of mean intensity and mean abundance were estimated with 20000 bootstrap replications using the statistical software Quantitative Parasitology v.3 (Reiczigel \& Rózsa 2005). Species richness was computed as the mean number of parasite species present per host examined at the infracommunity (individual dolphin) level. The component community was expressed as the total number of parasite species found. Site selection was analyzed for each helminth species on an infrapopulation basis. The distribution of the most prevalent species across the stomach chambers was determined at the infra- and component population levels, following Aznar et al. (2003).

Voucher specimens were deposited at the Natural History Museum of London, UK (Accession numbers: Pholeter gastrophilus, NHMUK 2013.11.29.1-2; Braunina cordiformis, NHMUK 2013.11.29.3-4; Braunina cordiformis, NHMUK 2013.11.29.5-8; and Synthesium tursionis, NHMUK2013.11.29.9). Nematodes and acanthocephalans were added to the collections of the Marine Mammals Laboratory (CENPAT-CONICET, Puerto Madryn, Argentina) and the Marine Zoology Unit, University of Valencia.

\section{Diet}

The dolphins' diet was characterized by diagnosing hard items (otoliths, bones, and cephalopod beaks) recovered from stomach contents. Intact prey (rarely found) were immediately identified, measured with digital calipers $( \pm 0.01 \mathrm{~mm})$ and weighed with an electronic balance $( \pm 0.01 \mathrm{~g})$. All prey remains were identified to the lowest possible taxonomic level using the reference collections of the Marine Mammals Laboratory (CENPAT-CONICET, Puerto Madryn, Argentina) and the IBMPAS (San Antonio Oeste, Argentina), and published catalogs (Clarke 1986, Gosztonyi \& Kuba 1996, Volpedo \& Echeverría 2000). The total number of consumed fish was determined from counts of left, right and unassigned otoliths. The minimal number per species was obtained as the sum of half the number of otoliths rounded up to the nearest whole number. The number of cephalopods was estimated as the maximum number of lower or upper beaks (Pierce \& Boyle 1991). The size (total length [TL] of fish and dorsal mantle length [DML] of squid in $\mathrm{cm}$ ) and wet weight (g) of prey was estimated from hard parts with allometric regressions. To minimize the underestimation of length or weight, only undamaged otoliths and beaks were measured. When digested or broken pieces were found in a stomach, the measurements for these elements were assigned from a random sample of undigested and whole parts from the same stomach (Koen Alonso et al. 1998). The importance of prey was determined using the percent frequency of incidence $(\% \mathrm{FO})$, the percentage by number $(\% \mathrm{~N})$, the percentage by estimated wet weight $(\% \mathrm{~W})$ and the index of relative importance (\%IRI; Pinkas et al. 1971, modified by Cortés 1997).

\section{RESULTS}

\section{Parasite fauna}

All bottlenose dolphins harbored helminths. A total of 6477 specimens were collected, of which 78 were nematodes, 6046 acanthocephalans and 352 digeneans. The gastrointestinal component community was composed of 7 species: the nematodes Anisakis simplex s.l. and Pseudoterranova decipiens; the acanthocephalans Corynosoma cetaceum and C. australe; and the digeneans Braunina cordiformis, Pholeter gastrophilus and Synthesium tursionis.

Infection parameters (prevalence, mean intensity and mean abundance) are shown in Table 2 . The 2 
Table 2. Tursiops truncatus. Infection parameters for the helminth species in stomachs $(\mathrm{n}=6)$ and/or intestines $(\mathrm{n}=5)$ of bottlenose dolphins from Patagonia, Argentina

\begin{tabular}{|c|c|c|c|c|c|c|c|}
\hline \multirow{2}{*}{$\begin{array}{l}\text { Helminth species } \\
\text { Nematoda }\end{array}$} & \multicolumn{2}{|c|}{$\begin{array}{c}\text { Prevalence } \\
(95 \% \mathrm{CI})\end{array}$} & \multicolumn{2}{|c|}{$\begin{array}{l}\text { Intensity } \\
\text { Mean (95\% CI) }\end{array}$} & \multirow[t]{2}{*}{ Range } & \multicolumn{2}{|c|}{$\begin{array}{c}\text { Abundance } \\
\text { Mean }(95 \% \text { CI) }\end{array}$} \\
\hline & & & & & & & \\
\hline Anisakis simplex s.l. & 83.3 & $(41.1-99.2)$ & 10.4 & $(3.0-28.4)$ & $1-35$ & 8.7 & $(2.33-25.3)$ \\
\hline Pseudoterranova decipiens & 16.7 & $(0.9-58.9)$ & 301.0 & & & 50.2 & $(0-100)$ \\
\hline \multicolumn{8}{|l|}{ Acanthocephala } \\
\hline Corynosoma cetaceum & 83.3 & $(41.1-99.2)$ & 1198.8 & $(349-1520)$ & $90-1629$ & 999 & $(287-1460)$ \\
\hline Corynosoma australe ${ }^{\mathrm{a}}$ & 40.0 & $(7.6-81.1)$ & 26.0 & $(2.0-50.0)$ & $2-50$ & 10.4 & $(0-30.4)$ \\
\hline \multicolumn{8}{|l|}{ Trematoda } \\
\hline Braunina cordiformis & 50.0 & $(15.3-84.7)$ & 11.7 & $(2.0-19.3)$ & $2-25$ & 5.8 & $(0.67-17)$ \\
\hline Pholeter gastrophilus & 33.3 & $(6.3-72.9)$ & 9.0 & $(8.0-9.0)$ & $8-10$ & 3.0 & $(0-6.3)$ \\
\hline Synthesium tursionis ${ }^{\text {a }}$ & 40.0 & $(7.6-81.1)$ & 12.5 & $(1.0-12.5)$ & $1-24$ & 5.0 & $(0-14.8)$ \\
\hline
\end{tabular}

most prevalent species (>80\%) were the nematode Anisakis simplex and the acanthocephalan Corynosoma cetaceum. A. simplex occurred free in the forestomach, main stomach and pyloric stomach (Table 3). No gastric ulcers associated with this species were found. By contrast, C. cetaceum, the parasite with the highest mean abundance and intensity, was fixed to the wall of the main stomach, pyloric stomach and duodenal ampulla, reaching the highest relative abundance in the pyloric stomach (75.5 \pm 42.4; Table 3). Only 1 host harbored Pseudoterranova decipiens, mainly in the forestomach $(83.7 \%$; Table 3 ) and at high intensity (301; Table 2). The gastric digeneans Braunina cordiformis and Pholeter gastrophilus had a prevalence of $50 \%$ and $33.3 \%$, respectively (Table 2). Adults of $B$. cordiformis were attached to the wall of the main stomach, pyloric stomach and duodenal ampulla and, in the same chambers, adults of $P$. gastrophilus were found in gastric cysts (Table 3). Only 3 helminth species were identified from the intestine: Corynosoma australe and Synthesium tursionis, with similar prevalence (40.0\%; Table 2 ), and 1 ind. of $C$. cetaceum, probably due to migration from the stomach. There was no clear distribution pattern of $C$. australe and $S$. tursionis, which were recovered from the duodenum to the large intestine.

All helminth species were found in adult stages. In addition, 4 forms were found either as third (L3) or fourth-stage (L4) larvae (the nematodes Anisakis simplex and Pseudoterranova decipiens) or putative juveniles (Corynosoma australe and Synthesium tursionis) (Table 3 ). The nematode $A$. simplex was present mainly at larval stage $(92.3 \%$ of ind.; $8 \mathrm{~L} 3 \mathrm{~s}$ and 40 L4s from 5 hosts), and larvae were identified as Type 1 (A. simplex). This morphotype includes 5 spe- cies, i.e. the 3 sibling species of the $A$. simplex species complex (A. simplex subspecies, A. simplex C and $A$. pegreffii), A. typica and $A$. ziphidarum, which cannot be identified at the larval stage (Mattiucci et al. 2002). Regarding P. decipiens, larvae comprising $53 \mathrm{~L} 3 \mathrm{~s}$ and $148 \mathrm{~L} 4 \mathrm{~s}$ (66.8\% of ind.) were recovered from the host's stomach. This species also comprises genetically differentiated sibling species ( $P$. decipiens complex: P. decipiens [s.s.], P. krabbei, P. bulbosa, $P$. azarasi and $P$. decipiens E) with particular geographic and host distributions (Mattiucci et al. 1998, Paggi et al. 2000, Mattiucci \& Nascetti 2008). Putative juveniles of C. australe (2 ind.) and $S$. tursionis (21 ind.) were recovered from the intestine of one host.

At infracommunity level, species richness ranged from 1 to 5 species, with a mean of 3.33 (95\% CI: 1.83 to 4.0$)$. One host $(16.7 \%)$ was infected with 1 helminth species; 2 (33.3\%) with 3 species; 2 (33.3\%) with 4 species, while a single host $(16.7 \%)$ harbored 5 parasite species. Corynosoma cetaceum dominated the infracommunities, accounting for on average $77.6 \pm 40.1 \%$ of the total gastrointestinal helminths.

\section{Diet}

Five bottlenose dolphins had food remains in their stomachs. In general, stomach contents were in an advanced state of digestion, and mostly composed of hard parts (beaks, bones and otoliths). In total, 103 prey items were recorded, with a total estimated biomass of $22.3 \mathrm{~kg}$ and a mean $\pm \mathrm{SD}$ of $7.4 \pm 4.6 \mathrm{~kg}$ per stomach. The mean number of prey items per stomach was $20.6 \pm 0.014$.

Stomach contents contained almost exclusively fish, comprising $77.7 \%$ of prey items (6 species, 80 ind.), 


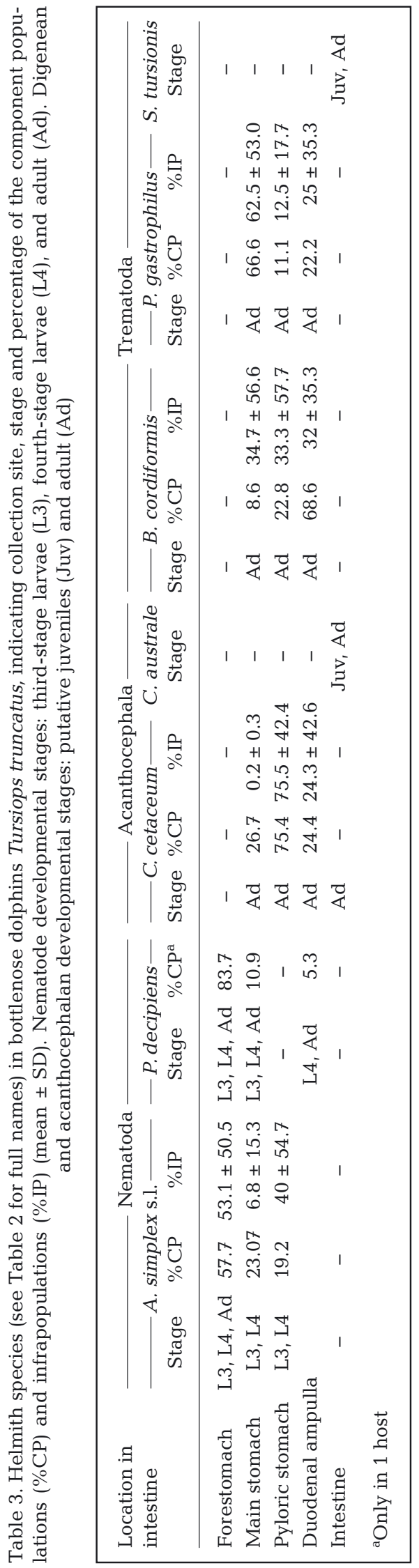

while the remainder was comprised of cephalopods (4 species, 20 ind.) and crustaceans ( 2 ind.; Table 4 ). Pouched lamprey Geotria australis was the most important prey $(\% \mathrm{IRI}=69.3 \%)$, representing $64.5 \%$ of the estimated weight and $49.5 \%$ of the total number of prey. Southwest Atlantic butterfish Stromateus brasiliensis ranked second in importance $(\%$ IRI $=$ $14.09 \%$ ), representing $17.5 \%$ of the total number and $28.9 \%$ of the total weight of prey, with an overall occurrence of $20 \%$. Two species of cephalopods, the Patagonian squid Loligo gahi and Patagonian octopus Octopus tehuelchus, were also prevalent in the bottlenose dolphins' diet, with \%IRI $>5 \%$. In terms of ecological groups, benthic species were dominant.

\section{DISCUSSION}

Bottlenose dolphins from Patagonia in the southwestern Atlantic were found to harbor 7 gastrointestinal helminth species, 5 of which infect other odontocete species: Corynosoma cetaceum, Braunina cordiformis, Anisakis simplex, Pholeter gastrophilus and Synthesium tursionis (Herreras et al. 1997, BerónVera et al. 2008). The 3 latter species also infect $T$. truncatus in the northern hemisphere (Bowie 1984, Raga et al. 1985a,b, Abollo et al. 1998, Aznar et al. 2006, Quiñones et al. 2013). The other 2 helminths, $C$. australe and Pseudoterranova decipiens, commonly infect pinnipeds (Aznar et al. 2004, Sardella et al. 2005, Hernández-Orts et al. 2013), and their finding in bottlenose dolphins constitutes a new host record.

The gastric helminths were differentially distributed across stomach chambers. According to site selection, the nematodes occurred mostly in the forestomach, Pholeter gastrophilus in the main stomach, Corynosoma cetaceum in the pyloric stomach and Braunina cordiformis in the duodenal ampulla. Two species, Corynosoma australe and Synthesium tursionis, were restricted to the intestine (Table 3). Each stomach chamber and intestinal section in a dolphin can be considered as a separate microhabitat (Berón-Vera et al. 2007).

Infection data for Anisakis simplex indicated high prevalence, probably reflecting its incidence in intermediate hosts due to its low host specificity (Smith \& Wootten 1978). However, its intensity was relatively low in bottlenose dolphins. Similar levels of infection have been reported in other coastal cetaceans from the southwestern Atlantic, possibly related to low transmission rates due to low availability of intermediate hosts in this ecosystem (Dans et al. 1999, Aznar et al. 2003, Berón-Vera et al. 2001, 2007). The structure of 
Table 4. Tursiops truncatus. Diet composition recovered from bottlenose dolphins off Patagonia. EG: ecological group of the prey (B: benthic; DB: demersal-benthic; DP: demersal-pelagic; P: pelagic; NA: not assigned); \%FO: percent frequency of occurrence; \% $\mathrm{N}$ : percentage by number; \%W: percentage by regression-estimated wet weight; \%IRI: percent of index of relative importance; N: number of prey items

\begin{tabular}{|lrrrrrr|}
\hline Prey species & EG & $\% \mathrm{FO}$ & $\% \mathrm{~N}$ & $\% \mathrm{~W}$ & $\% \mathrm{IRI}$ & $\mathrm{N}$ \\
\hline Fish & & $\mathbf{6 0 . 0}$ & $\mathbf{7 7 . 7}$ & $\mathbf{9 8 . 4}$ & $\mathbf{8 8 . 9}$ & $\mathbf{8 0}$ \\
Geotria australis & $\mathrm{B}$ & 40.0 & 49.5 & 64.5 & 69.3 & 51 \\
Stromateus brasiliensis & $\mathrm{P}$ & 20.0 & 17.5 & 28.9 & 14.1 & 18 \\
Acanthistius brasilianus & $\mathrm{D}$ & 20.0 & 3.9 & 2.2 & 1.8 & 4 \\
Austrolycus depressiceps & $\mathrm{B}$ & 20.0 & 1.9 & 2.7 & 1.4 & 2 \\
Patagonotothen ramsayi & $\mathrm{D}$ & 20.0 & 1.9 & 0.05 & 0.6 & 2 \\
Merluccius hubbsi & $\mathrm{D}$ & 20.0 & 1.0 & 0.08 & 0.3 & 1 \\
Unknown fish & $\mathrm{NA}$ & 20.0 & 1.9 & & & 2 \\
Cephalopods & & $\mathbf{6 0 . 0}$ & $\mathbf{1 9 . 4}$ & $\mathbf{1 . 5}$ & $\mathbf{1 0 . 6}$ & $\mathbf{2 0}$ \\
Loligo gahi & $\mathrm{D}$ & 40.0 & 8.7 & 0.3 & 5.5 & 9 \\
Octopus tehuelchus & $\mathrm{B}$ & 40.0 & 7.8 & 0.9 & 5.3 & 8 \\
Enteroctopus megalocyathus & $\mathrm{B}$ & 20.0 & & 0.2 & 0.7 & 2 \\
Loligo sanpaulensis & $\mathrm{D}$ & 20.0 & 1.0 & & & 1 \\
Crustaceans & & $\mathbf{2 0 . 0}$ & $\mathbf{2 . 9}$ & $\mathbf{0 . 0 7}$ & $\mathbf{0 . 5}$ & $\mathbf{3}$ \\
Artemesia longinaris & $\mathrm{D}$ & 20.0 & 1.9 & 0.05 & 0.6 & 2 \\
Unknown crab & $\mathrm{B}$ & 20.0 & 1.0 & 0.02 & 0.3 & 1 \\
& & & & & & 103 \\
\hline
\end{tabular}

A. simplex infrapopulations in bottlenose dolphins also follows the same pattern as other odontocetes. Larvae and adults are mainly found in the first stomach, suggesting that individuals of $A$. simplex tend to select the site where digestion begins (Aznar et al. 2003, Berón-Vera et al. 2007, 2008). A. simplex adults were restricted to the forestomach in bottlenose dolphins, as reported in Delphinus delphis and Pontoporia blainvillei (Aznar et al. 2003, Berón-Vera et al. 2001). Aznar et al. (2003) proposed that this restriction of $A$. simplex adults to the first chamber may reflect a mating enhancement strategy, or indicate that adults have stronger requirements for the resources provided by the forestomach. Moreover, the high prevalence of larval stages in numerous hosts may be interpreted as recent $A$. simplex recruitment through diet; it might also suggest that bottlenose dolphins are not its most common final host in the area (see below). The influx of parasites through coastal food webs enhances opportunities for many parasites to make contact with incidental hosts, in which they may or may not manage to reproduce at the ecological time, depending on compatibility filters (Raga et al. 2009).

The nematode Pseudoterranova decipiens was recovered from only 1 host (specimen Tur tru 002), which was afflicted with uterine adenocarcinoma (Sánchez et al. 2002). The poor health status of this host may have influenced the high infection rate of $P$. decipiens, which is typically observed in the gastrointesti- nal tract of South American sea lions Otaria flavescens and fur seals Arctocephalus australis from the same area (Hernández-Orts et al. 2013). Aside from the accidental nature of this parasite infection, $P$. decipiens microhabitat preference corresponded to the pattern described for anisakids, with high prevalence in the first stomach chamber.

Corynosoma cetaceum showed the highest mean abundance and intensity in bottlenose dolphins, and dominated the infracommunities (Tables 2 $\& 3)$. This species typically matures in the stomach and upper duodenum of its definitive cetacean hosts (Aznar et al. 2001), following a similar microhabitat selection pattern as Pontoporia blainvillei (Kagei et al. 1976, Aznar et al. 1994) and Delphinus delphis (Berón-Vera et al. 2007). Aznar et al. (2001) suggest that the pyloric stomach may provide C. cetaceum a larger space in which to settle and reproduce. Considering its geographical range, the occurrence of this acanthocephalan in dolphins from the coast of Buenos Aires Province and northern Patagonia is possibly associated with the availability of intermediate hosts and host-parasite specificity. Indeed, $D$. delphis, P. blainvillei and Tursiops truncatus might be required as final hosts for C. cetaceum in this area.

The other acantochephalan species, Corynosoma australe, is a widespread parasite in the intestine of otariids inhabiting cold-temperate waters of the Southern Hemisphere and may accidentally infect other marine mammals through their prey (Zdzitowiecki 1991). In Patagonia, Hernández-Orts et al. (2013) reported that $C$. australe was the most prevalent and abundant parasite in Otaria flavescens and Arctocephalus australis. Among small cetacean species, immature specimens of $C$. australe can inhabit the stomach of Lagenorhynchus obscurus (Dans et al. 1999), while both mature and immature individuals can occupy the posterior-most region of the intestine of the spectacled porpoise Phocoena dioptrica (Berón-Vera et al. 2008). In this study, the only 2 bottlenose dolphins harboring $C$. australe in their intestines were collected over a large spatio-temporal scale, suggesting that this dolphin species may be an occasional host for C. australe and may have been infected by consuming food resources of the definitive sympatric host. 
The family Brauninidae is specific to delphinids; Braunina cordiformis attaches to the stomach lining and the duodenal ampulla (Schryver et al. 1967). This species was previously recorded in the stomach of Tursiops truncatus, marine tucuxi dolphin Sotalia fluviatilis (Santos et al. 1996) and estuarine dolphin S. guianensis (Marigo et al. 2010) from the southeastern coast of Brazil. B. cordiformis has also been found infecting Lagenorhynchus obscurus (Dans et al. 1999), Cephalorhynchus commersonii (BerónVera et al. 2001) and Delphinus delphis (Berón-Vera et al. 2007) in Patagonia.

The digenean Pholeter gastrophilus is a wellknown generalist and cosmopolitan parasite of odontocetes, and typically resides within fibrotic nodules in the submucosa of the glandular region of the stomach (Migaki et al. 1971). In small cetaceans off Patagonia, P. gastrophilus is considered uncommon, infecting Delphinus delphis (Berón-Vera et al. 2007) and Lagenorhynchus obscurus (Dans et al. 1999) with low prevalence (16 in D. delphis and 4.35 in L. obscurus) and intensity $(4.0 \pm 3.38$ in $D$. delphis and 1 in L. obscurus). These values are slightly lower than parameters estimated in Tursiops truncatus; by contrast, P. gastrophilus was found in over $50 \%$ of Cephalorhynchus commersonii individuals (BerónVera et al. 2008). As described by Aznar et al. (2006) for bottlenose dolphins from the western Mediterranean, we also found that $P$. gastrophilus tended to settle in the main stomach. Different hypotheses have been formulated to explain microhabitat selection by this parasite, but the distribution pattern is not unique, and seems to be passively driven by features of the diet and digestive physiology of each host species (Aznar et al. 2006).

Synthesium tursionis is another cosmopolitan intestinal digenean which has been reported in at least 17 odontocete species (Bowie 1984, Fernández et al. 2003, 2004, Marigo et al. 2008, 2010). In the Mediterranean Sea, this parasite exhibits high specificity for the bottlenose dolphin (Raga et al. 1985a, Fernández et al. 1994, Quiñones et al. 2013), while in the southwestern Atlantic it infects not only Tursiops truncatus (Marigo et al. 2008) but also Sotalia guianensis (Mrigo et al. 2010). Regarding parasite stage, Quiñones et al. (2013) found a high prevalence of $S$. tursionis adults in the bottlenose dolphins from the Mediterranean Sea. As for Anisakis simplex, the wide range of larval stages observed (84\% of total ind.) in southwestern Atlantic samples may suggest that $T$. truncatus is an incidental host, although it might well represent a case of recent recruitment. Similar to Braunina cordiformis and Pholeter gas- trophilus, nothing is known about its life cycle, despite its widespread distribution.

Most marine mammal parasites are transmitted to the definitive host through their prey. Previous studies on the diet of bottlenose dolphins along the Argentinean coast are scarce due to their small population size and the fact they are seldom stranded or caught. Therefore, this study provides the first report on dolphin diet composition in this area, providing clues on potential parasite transmission routes. Among the prey identified, the pouched lamprey represented the highest relative contribution to Tursiops truncatus diet, but parasite fauna of this species has been poorly described. Lethbridge et al. (1983) reported the presence of plerocercoid larvae of Pelichnobothrium sp. and Hepatoxylon trichiuri, and recently Bao et al. (2013) recorded the presence of Anisakis simplex in the sea lamprey Petromyzon marinus; therefore, the role of lamprey in parasite transmission is unclear. On the Argentine continental shelf, the primary paratenic hosts known for A. simplex are the Argentine shortfin squid Illex argentinus (González \& Kroeck 2000), the Argentine anchovy Engraulis anchoita (Timi 2003), and the common hake Merluccius hubbsi (Sardella \& Timi 2004). However, these prey are not important components of the T. truncatus diet. Regarding the life cycle of Corynosoma cetaceum and C. australe, juveniles of both species have been found in at least 13 fish species on the Argentine continental shelf (see Timi et al. 2011). None of these prey species were identified from the dolphin stomachs analyzed here; however, most of them exhibit benthic habits and may represent potential prey in the Patagonian ecosystem. The non-specificity of the larval stages and the ecological ubiquity of acanthocephalans might have favored the high infection rates found in the bottlenose dolphin.

The parasite community of Tursiops truncatus is species-poor, and more so when we omit the parasite taxa for which the bottlenose dolphin is an uncommon host. This pattern has been described for marine mammals worldwide (Aznar et al. 2001). In Patagonia, parasitological studies on Delphinus delphis and Lagenorhynchus obscurus, sympatric species to bottlenose dolphins, reported 5 helminth species in their gastrointestinal tract, most of which we also identified in this study (Dans et al. 1999, Berón-Vera et al. 2007). This suggests a high overlap of the parasite community among these 3 dolphin species. However, common and dusky dolphins rely more on pelagic fish or squid species, while bottlenose dolphins share preponderantly bentho-demersal prey, more similar to the South American sea lion. According to the lit- 
erature, at a local scale, the parasite fauna of pelagic species tends to be distinctive and comparatively poor compared to that of coastal hosts. This is due to the absence of intermediate hosts; thus, the likelihood of parasite exchange is decreased and infective stages are diluted in the pelagic environment (Hoberg \& Adams 2000, Raga et al. 2009). Therefore, one might expect community species richness of parasites inhabiting bottlenose dolphins, a neritic species, to be higher than in pelagic species such as $D$. delphis and L. obscurus. Nevertheless, species richness is quite similar between them (considering the data available for $D$. delphis corresponds only to the gastric component; Dans et al. 1999, Berón-Vera et al. 2007), and our findings reveal there is a strong local influence shaping helminth communities in the gastrointestinal tract of bottlenose dolphins. To fully understand community similarity between host species and parasite transmission routes, we need additional data on host diet and parasite lifecycles for the southwestern Atlantic.

Acknowledgements. We are thankful to M. Koen-Alonso, B. Berón-Vera, G. Svendsen and D. Vales for their help in animal recovery and technical assistance. Thanks are due to colleagues at the Marine Zoology Unit (Cavanilles Institute of Biodiversity and Evolutionary Biology, University of Valencia) for collection and preparation of the worms, especially to P. Mateu and N. Fraija. The study was supported by the Agencia Nacional de Promoción Científica y Tecnológica of Argentina (Projects BID 1728/OC-AR PICT 11679; PID2003-No. 371; PICT2006 Start up No. 1575), PNUD ARG 02/018 and Consejo Nacional de Investigaciones Científicas y Técnicas (CONICET), and CGL2009-07465 (Ministerio de Ciencia e Innovación, España).

\section{LITERATURE CITED}

Abollo E, López A, Gestal C, Benavente P, Pascual S (1998) Macroparasites in cetaceans stranded on the northwestern Spanish Atlantic coast. Dis Aquat Org 32:227-231

> Aznar FJ, Balbuena JA, Raga JA (1994) Helminth communities of Pontoporia blainvillei (Cetacea: Pontoporiidae) in Argentinian waters. Can J Zool 72:702-706

Aznar FJ, Raga JA, Corcuera J, Monzón F (1995) Helminths as biological tags for franciscana (Pontoporia blainvillei) (Cetacea, Pontoporiidae) in Argentinian waters. Mammalia 59:427-435

Aznar FJ, Balbuena JA, Fernández M, Raga JA (2001) Living together: the parasites of marine mammals. In: Evans PGH, Raga JA (eds) Marine mammals: biology and conservation. Plenum Publishers, New York, NY, p 385-423

> Aznar FJ, Herreras MV, Balbuena JA, Raga JA (2003) Population structure and habitat selection by Anisakis simplex in four Odontocete species from northern Argentina. Comp Parasitol 70:66-71

Aznar FJ, Cappozzo HL, Taddeo D, Montero FE, Raga JA (2004) Recruitment, population structure, and habitat selection of Corynosoma australe (Acanthocephala) in
South American fur seals, Arctocephalus australis, from Uruguay. Can J Zool 82:726-733

Aznar FJ, Fognani P, Balbuena JA, Pietrobelli M, Raga JA (2006) Distribution of Pholeter gastrophilus (Digenea) within the stomach of four odontocete species: the role of the diet and digestive physiology of hosts. Parasitology 133:369-380

Bao M, Garci ME, Annio JM, Pascual S (2013) First report of Anisakis simplex (Nematoda, Anisakidae) in the sea lamprey (Petromyzon marinus). Food Contr 33:81-86

Berón-Vera B, Pedraza SN, Raga JA, Gil de Pertierra A, Crespo EA, Koen-Alonso M, Goodall RNP (2001) Gastrointestinal helminths of Commerson's dolphins Cephalorhynchus commersonii from central Patagonia and Tierra del Fuego. Dis Aquat Org 47:201-208

Berón-Vera B, Crespo EA, Raga JA, Fernández M (2007) Parasite communities of common dolphins (Delphinus delphis) from northern Patagonia: the relation with host distribution and diet and comparison with sympatric hosts. J Parasitol 93:1056-1060

Berón-Vera B, Crespo EA, Raga JA (2008) Parasites in stranded cetaceans of Patagonia. J Parasitol 94:946-948

> Bowie JY (1984) Parasites from an Atlantic bottle-nose dolphin (Tursiops truncatus), and a revised checklist of parasites of this host. NZ J Zool 11:395-398

Bush AO, Lafferty KD, Lotz JM, Shostak AW (1997) Parasitology meets ecology on its own terms: Margolis et al. revisited. J Parasitol 83:575-583

Byers JE (2009) Including parasites in food webs. Trends Parasitol 25:55-57

Clarke MR (1986) Cephalopods in the diet of odontocetes. In: Bryden MM, Harrison R (eds) Research on dolphins. Oxford University Press, Oxford, p 281-321

Cortés E (1997) A critical review of methods of studying fish feeding based on analysis of stomach contents: application to elasmobranch fishes. Can J Fish Aquat Sci 54: 726-738

Coscarella MA, Dans SL, Degrati M, Garaffo GV, Crespo EA (2012) Bottlenose dolphins at the southern extreme of the south-western Atlantic: local population decline? J Mar Biol Assoc UK 92:1843-1849

Dailey MD, Brownell RL Jr (1972) A checklist of marine mammal parasites. In: Ridgway $\mathrm{SH}$ (ed) Mammals of the sea: biology and medicine. Charles C Thomas, Springfield, IL, p 528-589

> Dans S, Reyes L, Pedraza S, Raga JA, Crespo EA (1999) Gastrointestinal helminths of the dusky dolphin, Lagenorhynchus obscurus (Gray, 1828), off Patagonia, in the southwestern Atlantic. Mar Mamm Sci 15:649-660

> Dubey JP, Zarnke R, Thomas NJ, Wong SK and others (2003) Toxoplasma gondii, Neospora caninum, Sarcocystis neurona, and Sarcocystis canis-like infections in marine mammals. Vet Parasitol 116:275-296

Fernández M, Balbuena JA, Raga JA (1994) Hadwenius tursionis (Marchi, 1873) n. comb. (Digenea, Campulidae) from the bottlenose dolphin Tursiops truncatus (Montagu, 1821) in the western Mediterranean. Syst Parasitol 28:223-228

Fernández M, Agustí C, Aznar FJ, Raga JA (2003) Gastrointestinal helminths of Risso's dolphin Grampus griseus from the western Mediterranean. Dis Aquat Org 55:73-76

Fernández M, Aznar FJ, Montero FE, Georgiev BB, Raga JA (2004) Gastrointestinal helminths of Cuvier's beaked whales, Ziphius cavirostris, from the western Mediterranean. J Parasitol 90:418-420 
Georgiev B, Biserkov V, Genov T (1986) In toto staining method for cestodes with iron acetocarmine. Helminthologia 23:279-281

Geraci JR, Lounsbury VJ (2005) Marine mammals ashore: a field guide for strandings, 2nd edn. National Aquarium in Baltimore, Baltimore, MD

González RA, Kroeck MA (2000) Enteric helminths of the shortfin squid Illex argentinus in San Matías Gulf (Argentina) as stock determinants. Acta Parasitol 45: 89-93

Gosztonyi A, Kuba L (1996) Atlas de huesos craneales y de la cintura escapular de peces costeros patagónicos. Informe Técnico del Plan de Manejo Integrado de la Zona Costera Patagónica 4, Argentina

Harwood J, Hall A (1990) Mass mortality in marine mammals: its implications for population-dynamics and genetics. Trends Ecol Evol 5:254-257

Hernández-Orts JS, Montero FE, Juan-García A, García NA, Crespo EA, Raga JA, Aznar FJ (2013) Intestinal helminth fauna of the South American sea lion Otaria flavescens and fur seal Arctocephalus australis from northern Patagonia, Argentina. J Helminthol 87:336-347

> Herreras MV, Kaarstad SE, Balbuena JA, Kinze CC, Raga JA (1997) Helminth parasites of the digestive tract of the harbour porpoise Phocoena phocoena in Danish waters: a comparative geographical analysis. Dis Aquat Org 28: 163-167

Hoberg EP, Adams A (2000) Phylogeny, history and biodiversity: understanding faunal structure and biogeography in the marine realm. Bull Scan Soc Parasitol 10: 19-37

> Hoberg EP, Klassen GJ (2002) Revealing the faunal tapestry: co-evolution and historical biogeography of hosts and parasites in marine systems. Parasitology 124:3-22

Kagei N, Tobayama T, Nagasaki Y (1976) On the helminthum of franciscana, Pontoporia blainvillei. Sci Rep Whales Res Inst 28:161-166

Koen Alonso M, Crespo EA, García NA, Pedraza SN, Coscarella M (1998) Diet of dusky dolphins, Lagenorhynchus obscurus, in waters off Patagonia, Argentina. Fish Bull (US) 96:366-374

Leatherwood S, Reeves RR (1990) The bottlenose dolphin. Academic Press, San Diego, CA

Lethbridge RC, Potter IC, Bray RA, Hilliard RW (1983) The presence of helminths in a Southern Hemisphere lamprey (Geotria australis Gray), with a discussion of the significance of feeding mechanisms in lampreys in relation to the acquisition of parasites. Acta Zool 64:79-83

MacKenzie K (2002) Parasites as biological tags in population studies of marine organisms: an update. Parasitology 124:S153-S163

Marigo J, Vicente ACP, Valente ALS, Measures L, Santos CP (2008) Redescription of Synthesium pontoporiae n. comb. with notes on $S$. tursionis and $S$. seymouri n. comb. (Digenea: Brachycladiidae Odhner, 1905). J Parasitol 94: 505-514

Marigo J, Ruoppolo V, Rosas FCW, Valente ALS, Oliveira MR, Dias RA, Catão-Dias JL (2010) Helminths of Sotalia guianensis (Cetacea: Delphinidae) from the south and southeastern coasts of Brazil. J Wildl Dis 46:599-602

> Mattiucci S, Nascetti G (2008) Advances and trends in the molecular systematics of Anisakid nematodes, with implications for their evolutionary ecology and hostparasite co-evolutionary processes. Adv Parasitol 66: 47-148
Mattiucci S, Paggi L, Nascetti G, Ishikura H and others (1998) Allozyme and morphological identification of Anisakis, Contracaecum and Pseudoterranova from Japanese waters (Nematoda, Ascaridoidea). Syst Parasitol 40: 81-92

Mattiucci S, Paggi L, Nascetti G, Portes Santos C and others (2002) Genetic markers in the study of Anisakis typica (Diesing, 1860): larval identification and genetic relationships with other species of Anisakis Dujardin, 1845 (Nematoda: Anisakidae). Syst Parasitol 51:159-170

Migaki G, van Dyke D, Hubbard RC (1971) Some histopathological lesions caused by helminthes in marine mammals. J Wildl Dis 7:281-289

> Nikolov PN, Cappozzo HL, Berón-Vera B, Crespo EA, Raga JA, Fernández M (2010) Cestodes from Hector's beaked whale (Mesoplodon hectori) and spectacled porpoise (Phocoena dioptrica) from Argentinean waters. J Parasitol 96:746-751

Paggi L, Mattiucci S, Gibson DI, Berland B, Nascetti G, Cianchi R, Bullini L (2000) Pseudoterranova decipiens A and B (Nematoda: Ascaridoidea): nomenclatural designation, morphological diagnostic characters and genetic markers. Syst Parasitol 45:185-197

Pierce GJ, Boyle PR (1991) A review of methods for diet analysis in piscivorous marine mammals. Oceanogr Mar Biol Annu Rev 29:409-486

Pinkas L, Oliphant MS, Iverson ILK (1971) Food habits of albacore, blue-fin tuna, and bonito in California waters. Fish Bull (US) 152:1-105

Quiñones R, Giovannini A, Raga JA, Fernández M (2013) Intestinal helminth fauna of bottlenose dolphin Tursiops truncatus and common dolphin Delphinus delphis from the western Mediterranean. J Parasitol 99:576-579

Raga JA, Carbonell E, Raduán A, Blanco C (1985a) Synthesium tursionis (Marchi, 1873) (Trematoda: Campulidae) parasite of Tursiops truncatus (Montagu, 1821) (Cetacea: Delphinidae) in the Spanish Mediterranean Sea. Rev Iber Parasitol 45:119-122

Raga JA, Carbonell E, Raduán A, Blanco C (1985b) Sobre la presencia de Pholeter gastrophilus (Kossack, 1910) (Trematoda: Troglotrematidae), en quistes estomacales de Tursiops truncatus y Stenella coeruleoalba (Cetacea: Delphinidae), en las costas españolas del Mediterráneo. Rev Iber Parasitol 45:123-128

Raga JA, Fernández M, Balbuena JA, Aznar FJ (2009) Parasites. In: Perrin WF, Würsig B, Thewissen JGM (eds) Encyclopedia of marine mammals. Academic Press, London, p 821-830

Reiczigel J (2003) Confidence intervals for the binomial parameter: some new considerations. Stat Med 22:611-621

Reiczigel J, Rózsa L (2005) Quantitative parasitology 3.0. Available at www.zoologia.hu/qp/

> Rózsa L, Reiczigel J, Majoros G (2000) Quantifying parasites in samples of hosts. J Parasitol 86:228-232

> Sánchez J, Kuba L, Berón-Vera B, Dans SL and others (2002) Uterine adenocarcinoma with generalised metastasis in a bottlenose dolphin Tursiops truncatus from northern Patagonia, Argentina. Dis Aquat Org 48:155-159

Santos CP, Rohde K, Ramos R, Di Beneditto AP (1996) Helminths of cetaceans on the southeastern coast of Brazil. J Helminthol 63:149-152

Sardella N, Timi J (2004) Parasites of Argentine hake in the Argentine Sea: population and infracommunity structure as evidence for host stock discrimination. J Fish Biol 65: 1472-1488 
Sardella NH, Mattiucci S, Timi JT, Bastida RO, Rodríguez DH, Nascetti G (2005) Corynosoma australe Johnston, 1937 and C. cetaceum Johnston and Best, 1942 (Acanthocephala: Polymorphidae) from marine mammals and fishes in Argentinian waters: allozyme markers and taxonomic status. Syst Parasitol 61:143-156

Schryver HF, Medway W, Williams JF (1967) The stomach fluke Braunina cordiformis in the Atlantic bottlenose dolphin. J Am Vet Med Assoc 151:884-886

Smith JW, Wootten R (1978) Anisakis and anisakiasis. Adv Parasitol 16:93-163

Timi JT (2003) Parasites of Argentine anchovy in the southwest Atlantic: latitudinal patterns and their use for discrimination of host populations. J Fish Biol 63: 90-107

Editorial responsibility: Michael Moore, Woods Hole, Massachusetts, USA
Timi JT, Rossin MA, Alarcos AJ, Braicovich PE, Cantatore DMP, Lanfranchi AL (2011) Fish trophic level and the similarity of non-specific larval parasite assemblages. Int J Parasitol 41:309-316

Volpedo AV, Echeverría DD (2000) Catálogo y claves de otolitos para la identificación de peces del mar Argentino. 1. Peces de importancia económica. Editorial Dunke, Buenos Aires

Wells RS, Scott MD (1999) Bottlenose dolphin Tursiops truncatus (Montagu, 1821). In: Ridgway SH, Harrison R (eds) Handbook of marine mammals, Vol 6: the second book of dolphins and the porpoises. Academic Press, San Diego, CA, p 137-182

Zdzitowiecki K (1991) Antarctic acanthocephala, Vol 3. Koeltz Scientific Books, Königstein

Submitted: August 12, 2013; Accepted: November 23, 2013

Proofs received from author(s): January 19, 2014 